\title{
Putative virulence genes and antibiotic resistance profiles of Campylobacter jejuni isolated from cats ${ }^{\#}$
}

\author{
Harun Hızlısoy ${ }^{1 *}$, İlknur Karaca Bekdik², Öznur Aslan², Kadir S. Gümüşsoy³, \\ and Serhat Hizlısoy ${ }^{4}$ \\ ${ }^{1}$ Department of Veterinary Public Health, Faculty of Veterinary Medicine, Erciyes University, Kayseri, Turkey \\ ${ }^{2}$ Department of Internal Medicine, Faculty of Veterinary Medicine, Erciyes University, Kayseri, Turkey \\ ${ }^{3}$ Department of Microbiology, Faculty of Veterinary Medicine, Erciyes University, Kayseri, Turkey \\ ${ }^{4}$ Department of Computer Engineering, The Faculty of Engineering, Cukurova University, Adana, Turkey
}

HIZLISOY, H., İ. KARACA BEKDIK, Ö. ASLAN, K. S. GÜMÜŞSOY, S. HIZLISOY: Putative virulence genes and antibiotic resistance profiles of Campylobacter jejuni isolated from cats. Vet. arhiv 90, 129-141, 2020.

\section{ABSTRACT}

Daily contact with cats is an important risk factor for human campylobacteriosis. The main goal of this study was to investigate the virulence genes and antibiotic resistances of $C$. jejuni isolated from the stools of cats brought to Erciyes University, Faculty of Veterinary Medicine, Training and Research Hospital Clinics. In the study, feces taken from different breeds and ages ( 1 month to 9 years) of 200 (116 female, 84 male) cats were examined between May 2017 and April 2018. Campylobacter spp. isolates were identified at genus and species level using genus specific multiplex PCR (mPCR), and the existence of $i a m, c a d \mathrm{~F}, c d t \mathrm{~A}, f a \mathrm{~A}, c e u \mathrm{E}, c d t \mathrm{C}, c d t \mathrm{~B}$ and $v i r B 11$ genes were found by PCR. The antimicrobial resistance and multidrug resitance (MDR) of the isolates were determined by disc diffusion test. By means of Enterobacterial Repetitive Intergenic Consensus Polymerase Chain Reaction (ERIC-PCR), the genetic relativeness of the isolates were revealed. In this study, 41 (20.5\%) of 200 stool samples were shown to be positive for Campylobacter spp. in the isolation of Campylobacter spp. from stool samples. In the positive samples, 14 of 22 (63.6\%) were from diarhoeic cats and 27 of $178(15.1 \%)$ were non-diarhoeic cats. Also, in total 71 Campylobacter spp. suspicious isolates were recovered from the 41 positive samples obtained. Phenotypic tests and PCR revealed that 65 isolates (20 from diarrhoeic and 45 from non-diarhoeic cat isolates) were identified as $C$. jejuni. The differences in isolation rate in relation to sex or age were not statistically significant $(\mathrm{P}>0.05)$. In terms of virulence genes, all C. jejuni isolates harbored at least five virulence genes. All isolates were positive for the $c a d \mathrm{~F}, c d t \mathrm{C}$ and $c e u \mathrm{E}$ genes, respectively. C. jejuni isolates contained $i a m, c a d \mathrm{~F}, c d t \mathrm{~A}, f l a \mathrm{~A}, c e u \mathrm{E}, c d t \mathrm{C}, c d t \mathrm{~B}$ and $v i r \mathrm{~B} 11$, at the rate of $19(29.2 \%)$, $65(100 \%), 64$ (98.4), 54 (83\%), 65 (100\%), 65 (100\%), 64 (98.4\%) and 22 (33.8\%) respectively. Moreover, $c d t$ A and $c d t \mathrm{~B}$ toxin genes were found in most of the isolates analysed. All $C$. jejuni isolates were susceptible to amoxicillin clavulanic acid. The highest resistances of the isolates were found as follows; 64 (98.4\%), 63 (96.9\%), 62 (95.3\%) for ciprofloxacin (CIP), trimethoprim sulfamethoxazole (SXT), nalidixic acid (NA) antibiotics, respectively. Multiple resistance of isolates was detected in the present study. Sixty-one (93.8\%) out of 65 isolates were resistant to three or more antibiotics, and the highest resistance levels to three and seven antimicrobials were observed in $23.1 \%$ and $15.3 \%$ of the isolates respectively. In the study, C. jejuni isolates were resistant to most antibiotics currently used, and had extraordinary virulence traits in cats which may constitute a non-negligible risk for public health.

Key words: Campylobacter jejuni; virulence; antibiotic resistance; ERIC-PCR

\footnotetext{
*Corresponding author:

Ass. Prof. Dr. Harun HIZLISOY Erciyes University, Faculty of Veterinary Medicine, Department of Veterinary Public Health, Kayseri-Turkey, E-mail. harunhzlsoy@hotmail.com; hizlisoy@erciyes.edu.tr
} 
\#A part of this study was presented in " $2^{\text {nd }}$ International Congress of Veterinary Microbiology, Antalya, Turkey, 16-19 October 2018 " as an oral presentation

\section{Introduction}

Campylobacter spp. is Gram negative, spiral, microaerophilic bacteria in the gastrointestinal tract in humans and animals (VANDAMME and DE LEY, 1991). The genus Campylobacter consists of 26 species and nine subtypes (KAAKOUSH et al., 2015; HEREDIA and GARCIA, 2018). In addition to cats and dogs, Campylobacter spp. is found as commensal in cattle, sheep, pigs and birds (HEREDIA and GARCIA, 2018). In humans, in addition to gastrointestinal disorders, Campylobacter spp. (especially C. jejuni and $C$. coli) can cause extra-intestinal findings, such as bacteremia, brain abscesses, meningitis, Guillain-Barre Syndrome and reactive arthritis (KAAKOUSH et al., 2015). Campylobacter spp. is also found in the gastrointestinal tracts of dogs and cats (BOJANIC et al., 2017). Daily contact with domestic cats is an important risk factor for human campylobacteriosis (LINDMARK et al., 2009). Campylobacter spp. is commonly isolated from feces of infected cats (ACKE, 2018). C. jejuni was first isolated from cats in England in 1977 and in the USA in 1980 (KAAKOUSH et al., 2015).

The poor identification of Campylobacter spp. as animal pathogens may result from the simultaneous presence of multiple strains or species with various pathogenetic characteristics. In routine diagnostic laboratories, typing of Campylobacter spp. is usually restricted to one colony per stool sample (KOENE et al., 2004). More than one subtype of Campylobacter spp. within the same species may be simultaneously detected as a causative agent in human and animal campylobacteriosis cases (KAYMAN et al., 2015).

Some authors reported that Campylobacter spp. isolates demonstrated resistances to the antibiotics currently used (including macrolides, fluoroquinolones and others) (KULKARNI et al., 2002; SANDBERG et al., 2002; GUPTA et al., 2004; ENGBERG et al., 2004; ANDRZEJEWSKA et al., 2013, SZCZEPANSKA et al., 2017; KUMAR et al., 2012).
In recent years, one of the significant threats to public health has been found to be multidrug resistant microorganisms (MDR) (MAGIORAKOS et al., 2012). MDR reported as a single isolate, was resistant to three or more antimicrobial classes (ABAY et al., 2012). Bacteria can develop multidrug resistance via the gathering of genes encoded for resistance to a single drug, or by increased expression of genes encoding multiple drug delivery pumps in a single cell (NIKAIDO, 2009).

In cats, few documents were found on the clinical symptoms of campylobacteriosis. In some studies, cats infected with Campylobacter spp. were clinically healthy, lacking other pathogens (FOX, 2012). Moreover, in the studies carried out on the pathogenesis of campylobacteriosis, motility, adhesion to intestinal epithelial cells, invasion to host cells, and cytotoxin production are mentioned as important virulence factors of Campylobacter spp. (CASABONNE et al., 2016). Various genes have been identified with regard to the virulence of campylobacters: flaA (Flagellin A), Cad $\mathrm{F}$ ( Campylobacter adhesion to fibronectin), $d n a \mathrm{~J}, r a c \mathrm{R}, c j 0588$ genes are present for adherence and colonization; virB11, cia $\mathrm{B}$ (Campylobacter invasion antigen $\underline{\mathrm{B}}$ ), pldA, iam (invasion-associated marker) genes are responsible for invasion; $c d t \mathrm{~A}$, $c d t \mathrm{~B}, c d t \mathrm{C}$ (cytolethal distending toxin $\mathrm{A}, \mathrm{B}$ and $\mathrm{C}$ ) genes are accountable for cytotoxin production; and $w l a \mathrm{~N}$ and $c g t \mathrm{~B}$ genes are related to Guillain-Barre syndrome (DATTA et al., 2003; MARTINEZ et al., 2006; KHOSHBAKHT et al., 2013; QUETZ et al., 2012; LARSON et al., 2008; KOOLMAN et al., 2016).

Due to the limited data about the virulence factors, antibiotic resistance and multiple drug resistance profiles of Campylobacter spp. in cats, we aimed to investigate the virulence genes and antibiotic resistance profiles of $C$. jejuni isolated from stool samples of 200 cats brought to Erciyes University, Faculty of Veterinary Medicine, Training and Research Hospital Clinics.

\section{Materials and methods}

Animals. The stool samples taken from different breeds and ages (1 month to 9 years) of 200 (116 
female, 84 male) cats, brought to Erciyes University, Faculty of Veterinary Medicine, Training-Research and Practice Hospital Clinics, between May 2017 and April 2018 in for the sake of a year-long study, with the permission of the pet owners. The samples were divided into two groups on the basis of history. One group comprised 22 animals out of the 200 cats identified as having diarrhea, and 178 cats in the other group did not show these symptoms, they were non-diarhoeic, and they did not have any infectious diseases or antimicrobial treatments (cats brought to the clinics for routine examinations and vaccination services). In this study, the cats were also divided into two groups as "younger than six months and older than six months" according to the literature (ACKE et al., 2006; 2009a). Regarding gender/sex, there were no established criteria, only the animal owners' declarations were taken into consideration.

Table 1. Age, gender, non-diarhoeic and diarrhoeic status of cats in the study

\begin{tabular}{|c|c|c|c|c|}
\hline & \multicolumn{2}{|c|}{ Diarrhoeic cats } & \multicolumn{2}{c|}{ Non-diarhoeic cats } \\
\cline { 2 - 5 } & $\begin{array}{c}\text { C. jejuni } \\
\text { Positive }\end{array}$ & $\begin{array}{c}\text { C. jejuni } \\
\text { Negative }\end{array}$ & $\begin{array}{c}\text { C. jejuni } \\
\text { Positive }\end{array}$ & $\begin{array}{c}\text { C. jejuni } \\
\text { Negative }\end{array}$ \\
\hline $\begin{array}{c}<6 \text { months } \\
(\mathrm{n}=125)\end{array}$ & $\mathbf{8}$ & $\mathbf{4}$ & $\mathbf{1 9}$ & $\mathbf{9 4}$ \\
\hline $\begin{array}{c}\text { Female } \\
(\mathrm{n}=76)\end{array}$ & 7 & 3 & 12 & 54 \\
\hline $\begin{array}{c}\text { Male } \\
(\mathrm{n}=49)\end{array}$ & 1 & 1 & 7 & 40 \\
\hline $\begin{array}{c}>6 \text { months } \\
(\mathrm{n}=75)\end{array}$ & $\mathbf{6}$ & $\mathbf{4}$ & $\mathbf{8}$ & $\mathbf{5 7}$ \\
\hline $\begin{array}{c}\text { Female } \\
(\mathrm{n}=40)\end{array}$ & 4 & 2 & 6 & 28 \\
\hline $\begin{array}{l}\text { Male } \\
(\mathrm{n}=35)\end{array}$ & 2 & 2 & 2 & 29 \\
\hline $\begin{array}{l}\text { Total } \\
(\mathrm{n}=200)\end{array}$ & $\mathbf{1 4}$ & $\mathbf{8}$ & $\mathbf{2 7}$ & $\mathbf{1 5 1}$ \\
\hline
\end{tabular}

Reference strain. Staphylococcus aureus ATCC 25923, Escherichia coli ATCC 25922 and Campylobacter jejuni ATCC 700819 were used as control strains.

Isolation, identification and molecular detection of virulence genes. Fecal swabs were kept in CaryBlair medium (Oxoid, CM0519, UK) no more than three hours before culturing. The stool samples were inoculated onto modified charcoal cefoperazone deoxycholate (mCCD) agar (Oxoid, CM739, UK), additionally supplemented with cefoperazone, amphotericin B and teicoplanin (CAT supplement, Oxoid, SR174, UK), and incubated at $42{ }^{\circ} \mathrm{C}$ for 48 $72 \mathrm{~h}$ under microaerobic conditions.

Presumed colonies were confirmed as Campylobacter spp. on the basis of cell morphology (Gray to white or metallic-highlighted colonies growth on a mCCD agar) after the incubation period, by phenotypic (colony morphology, Gram staining, oxidase test, catalase test and motion test) tests. Thereafter, all Campylobacter spp. isolates were identified at genus and species level using genus specific mPCR assay (WANG et al., 2002). For this purpose, template DNA was initially extracted using the InstaGene ${ }^{\mathrm{TM}}$ Matrix (Bio-Rad, USA) kit. Concentrations of the DNA samples $(\mu \mathrm{g} / \mu \mathrm{L})$ were measured by Qubit 3.0 fluorometer (Thermo Fisher, USA) and stored at $-20{ }^{\circ} \mathrm{C}$ until analysis. $\mathrm{mPCR}$ was carried out in a reaction mixture for each sample; $2.5 \mu \mathrm{L}$ DNA sample, $2.5 \mu \mathrm{L} 10 \mathrm{x}$ PCR buffer (Thermo Scientific, USA), $20 \mathrm{mM}$ $\mathrm{MgCl}_{2}$ (Vivantis, Malaysia), $0.2 \mathrm{mM} \mathrm{dNTP} \mathrm{mixture}$ (Thermo Scientific, USA), $0.5 \mu \mathrm{M} C$. jejuni and $C$. lari; $1 \mu \mathrm{M}$ C. coli and C. fetus, $2 \mu \mathrm{M}$ C. upsaliensis, $0.2 \mu \mathrm{M}$ Campylobacter $23 \mathrm{~S}$ rRNA primers and 1.25 U Taq polymerase (Thermo Scientific, USA) were prepared by adjusting the final concentration to 25 $\mu \mathrm{L}$ with sterile distilled water. DNA amplification was carried out including an initial denaturation step at $95{ }^{\circ} \mathrm{C}$ for $6 \mathrm{~min}$, followed by 30 cycles, denaturation at $95{ }^{\circ} \mathrm{C}$ for $0.5 \mathrm{~min}$, annealing at $59{ }^{\circ} \mathrm{C}$ for $0.5 \mathrm{~min}$, and extension at $72{ }^{\circ} \mathrm{C}$ for 0.5 min, ending with a final extension at $72{ }^{\circ} \mathrm{C}$ for 7 min. in a thermocycler (Arktic ${ }^{\mathrm{TM}}$ Thermal Cycler; Thermo Fisher, USA). As a result of amplification, the PCR products obtained were visualized using a UVP gel documentation system (Vilber Lourmat, France) after electrophoresis (Thermo EC 330, USA) for 90 minutes at $90 \mathrm{~V}$ in a $1.5 \%$ agarose gel. Campylobacter species were identified according to the band sizes (Table 2).

The presence of virulence genes, including iam, $c a d \mathrm{~F}, c d t \mathrm{~A}, c d t \mathrm{~B}, c d t \mathrm{C}, f l a \mathrm{~A}, c e u \mathrm{E}$, and $v i r B 11$, were determined by PCR, as described in earlier studies (KRUTKIEWICZ and KLIMUSZKO, 2010; CHANSIRIPORNCHAI and SASIPREEYAJAN, 
2009; DATTA et al., 2003; RIPABELLI et al., 2010) with modifications. PCRs for virulence genes were carried out in a reaction mixture: $4 \mu \mathrm{L}$ DNA sample, 10x PCR buffer with $\mathrm{KCl}$ (Thermo Scientific, USA), $1.5 \mathrm{mM} \mathrm{MgCl}_{2}$ (Vivantis, Malaysia), 250 $\mathrm{mM}$ dNTP mixture (Thermo Scientific, USA), $1 \mu \mathrm{M}$ each primers and $0.5 \mathrm{U}$ Taq polymerase (Thermo Scientific, USA) to adjust the final concentration to $40 \mu \mathrm{L}$ with sterile distilled water. The PCR protocol included denaturation at $94^{\circ} \mathrm{C}$ for 1 min., annealing at $52{ }^{\circ} \mathrm{C}$ for $1 \mathrm{~min}$. and extension at $72{ }^{\circ} \mathrm{C}$ for $1 \mathrm{~min}$. followed by 30 cycles, and a final extension at 72 ${ }^{\circ} \mathrm{C}$ for $5 \mathrm{~min}$. Negative and positive controls were used. Further, all the negative samples were tested. The amplified products were electrophoresed in a $1.5 \%(\mathrm{w} / \mathrm{v})$ TAE agarose gel at $100 \mathrm{~V}$ for $1 \mathrm{~h}$. The gel was visualized under UV light. The investigated primers and expected band size (bp) for MPCR and PCRs for virulence genes are summarized in Table 2.

Table 2. The Oligonucleotide Sequence and Predicted Sizes Used in the PCR

\begin{tabular}{|c|c|c|}
\hline Name & Sequence & Band size (bp) \\
\hline Prier-I (CJF) & 5'- ACT TCT TTA TTG CTT GCT GC - 3' & \multirow{2}{*}{323} \\
\hline Primer-II (CJR) & 5'- GCC ACA ACA AGT AAA GAA GC - 3' & \\
\hline Primer-I (CCF) & 5'- GTAAAACCAAAGCTTATCGTG -3' & \multirow{2}{*}{126} \\
\hline Primer-II (CCR) & 5'- TCCAGCAATGTGTGCAATG -3' & \\
\hline Primer-I (CLF) & 5'- TAGAGAGATAGCAAAAGAGA -3' & \multirow{2}{*}{251} \\
\hline Primer-II (CLR) & 5'- TACACATAATAATCCCACCC -3' & \\
\hline Primer-I (CUF) & 5'-AATTGAAACTCTTGCTATCC -3' & \multirow{2}{*}{204} \\
\hline Primer-II (CUR) & 5'- TCATACATTTTACCCGAGCT -3' & \\
\hline Primer-I (CFF) & 5'-GCAAATATAAATGTAAGCGGAGAG-3' & \multirow{2}{*}{435} \\
\hline Primer-II (CFR) & 5'- TGCAGCGGCCCCACCTAT-3' & \\
\hline 23SrRNA-F & 5'- TATACCGGTAAGGAGTGCTGGAG-3' & \multirow{2}{*}{650} \\
\hline 23SrRNA-R & 5'- ATCAATTAACCTTCGAGCACCG -3' & \\
\hline flaAF & 5'-ATGGGATTTCGTATTAACAC-3' & \multirow{2}{*}{1700} \\
\hline$f l a \mathrm{AR}$ & 5'-CTGTAGTAAATCTTAAAACATTTTG-3' & \\
\hline$c d t \mathrm{AF}$ & 5'-GGAAATTGGATTTGGGGCTATACT -3' & \multirow{2}{*}{165} \\
\hline$c d t \mathrm{AR}$ & 5'- ATCACAAGGATAATGGACAAT -3' & \\
\hline$c d t \mathrm{BF}$ & 5'- GTTAAAATCCCTGCTATCAACCA -3' & \multirow{2}{*}{495} \\
\hline$c d t \mathrm{BR}$ & 5'- GTTGGCACTTGGAATTTGCAAGGC -3' & \\
\hline$c d t \mathrm{CF}$ & 5'- TGGATGATAGCAGGGGATTTTAAC -3' & \multirow{2}{*}{555} \\
\hline$c d t \mathrm{CR}$ & 5'- TTGCACATAACCAAAAGGAAG -3' & \\
\hline $\operatorname{vir} \mathrm{B} 11 \mathrm{~F}$ & 5'- TCTTGTGAGTTGCCTTACCCCTTTT -3' & \multirow{2}{*}{494} \\
\hline virB11R & 5'- CCTGCGTGTCCTGTGTTATTTACCC -3' & \\
\hline$c e u \mathrm{EF}$ & 5'-CCTGCTCGGTGAAAGTTTTG-3' & \multirow{2}{*}{794} \\
\hline$c e u \mathrm{ER}$ & 5'-GATCTTTTTGTTTTGTGCTGC-3' & \\
\hline cadFR1BF & 5'- TTGAAGGTAATTTAGATATG-3' & \multirow{2}{*}{400} \\
\hline cadFR1BR & 5'- CTAATACCTAAAGTTGAAAC -3' & \\
\hline $\operatorname{iam} \mathrm{F}$ & 5'-GCGCAAAATATTATCACCC-3 & \multirow{2}{*}{518} \\
\hline $\operatorname{iam} \mathrm{R}$ & 5'-TTCACGACTACTATGCGG-3' & \\
\hline
\end{tabular}


Antibiotic susceptibility testing. The antibiotic susceptibilities of the isolates identified as $C$. jejuni were investigated by the disc diffusion method and the results were evaluated according to CLSI recommendations (CLSI, 2014). The following 16 antibiotics were used in the study: amoxicillin clavulanic acid (AMC, $30 \mu \mathrm{g}$ ), ciprofloxacin (CIP, $5 \mu \mathrm{g}$ ), trimethoprim sulfamethoxazole (SXT, 25 $\mu \mathrm{g}$ ), enrofloxacin (ENR, $5 \mu \mathrm{g}$ ), clindamycin (DA, $2 \mu \mathrm{g}$ ), nalidixic acid (NA, $30 \mu \mathrm{g}$ ), streptomycin (S, $10 \mu \mathrm{g}$ ), tetracycline (TE, $30 \mu \mathrm{g}$ ), doxycycline (DO, $30 \mu \mathrm{g}$ ), ampicillin (AMP, $10 \mu \mathrm{g}$ ), erythromycin (E, $15 \mu \mathrm{g})$, streptomycin $(\mathrm{S}, 10 \mu \mathrm{g})$, amikacin (AK, 30 $\mu \mathrm{g})$, gentamycin $(\mathrm{CN}, 10 \mu \mathrm{g})$, cefotaxime (CTX, $30 \mu \mathrm{g}$ ), and piperacillin-tazobactam (TZP, $110 \mu \mathrm{g}$ ), (Oxoid, UK). Multidrug resistance was evaluated as to whether a single isolate was resistant to three or more antibacterial classes.

Enterobacterial repetitive intergenic consensus polymerase chain reaction (ERIC-PCR). For molecular typing of the isolates, Enterobacterial Repetitive Intergenic Consensus Polymerase Chain Reaction (ERIC-PCR) was utilized (HOUF et al., 2002). In the test, ERIC1 and ERIC2 primers were used. Briefly, the PCR mixture was $50 \mu \mathrm{L}$ in total,

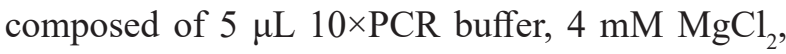
$5 \mathrm{U}$ Taq DNA polymerase, the final concentration for the dNTP mixture was $0.2 \mathrm{mM}, 25$ pmol for each primer and $1 \mu \mathrm{L}$ for template DNA. DNA amplification consisted of an initial denaturation at $94{ }^{\circ} \mathrm{C}$ and $5 \mathrm{~min}$, followed by 40 cycles of $94{ }^{\circ} \mathrm{C}$ for $1 \mathrm{~min}, 25^{\circ} \mathrm{C}$ for $1 \mathrm{~min}$ and $72{ }^{\circ} \mathrm{C}$ for $2 \mathrm{~min}$. The amplified products were resolved by electrophoresis in a $2 \%(\mathrm{w} / \mathrm{v})$ TAE agarose gel at $100 \mathrm{~V}$ for $1 \mathrm{~h}$. The gel was tested and evaluated by visual inspection under UV light.

Statistical analysis. Chi-square tests were used for the statistical analysis in the study, in order to compare the $C$. jejuni presence and gender, age and diarrhoea status of the cats, using the SPSS (Statistical Package for Social Sciences for Windows) 23.0 (Armonk, NY: IBM Corp.) program.

\section{Results}

In the study, $41(20.5 \%)$ of 200 stool swab samples from cats were positive for the presence of Campylobacter spp. In the positive samples, 14 of
$22(63.6 \%)$ were from diarhoeic cats, and 27 of 178 $(15.2 \%)$ were non-diarhoeic cats. The difference in isolation rate between the diarhoeic cats or nondiarhoeic cats was statistically significant $(\mathrm{P}<0.001$, $X^{2}$ :28.22). Also, in total 71 Campylobacter spp. suspicious isolates were recovered from the 41 positive samples obtained. Phenotypic tests and PCR revealed that 65 isolates ( 20 of them diarrhoeic and 45 non-diarhoeic cat isolates) were identified as $C$. jejuni, whereas the six remaining isolates were positive at genus but negative at species level. The age, gender, non- diarrhea and diarrhea status of $C$. jejuni positive cats are detailed in Table 1 . The differences in isolation rate in relation to sex $\left(\mathrm{P}>0.05, \mathrm{P}=0.064, X^{2}: 3.432\right)$ or age $(\mathrm{P}>0.05, \mathrm{P}=$ $\left.0.619, X^{2}: 0.247\right)$ in diarrhoeic and non-diarhoeic cats were not statistically significant. In 19 cat samples, more than one subtype of $C$. jejuni was also identified from each sample according to ERICPCR results. It was included that two subtypes of $C$. jejuni isolates were simultaneously found in 14 cat samples (three of them were diarrhoeic and 11 of them were non-diarhoeic cats) and three subtypes of $C$. jejuni isolates in five positive cat samples (two of them were diarrhoeic and three of them were non-diarhoeic cats).

In terms of virulence genes, all the $C$. jejuni isolates harbored at least five virulence genes. All isolates were positive for the $c a d \mathrm{~F}, c d t \mathrm{C}$ and $c e u \mathrm{E}$ genes, respectively. The $C$. jejuni isolates contained iam, $c a d \mathrm{~F}, c d t \mathrm{~A}, f l a \mathrm{~A}, c e u \mathrm{E}, c d t \mathrm{C}, c d t \mathrm{~B}$ and $v i r \mathrm{~B} 11$, at the rate of $19(29.2 \%), 65(100 \%), 64(98.4), 54$ $(83 \%), 65(100 \%), 65(100 \%), 64(98.4 \%)$ and $22(33.8 \%)$ respectively. Moreover, the $c d t \mathrm{~A}$ and $c d t \mathrm{~B}$ toxin genes were found in most of the isolates analyzed (Table 3). The iam gene was found in 7. $7 \%$ and $21.5 \%$ of the diarrhoeic and non-diarhoeic cat isolates, respectively. The $c a d \mathrm{~F}, c e u \mathrm{E}$ and $c d t \mathrm{C}$ genes were found in $30.7 \%$ and $69.2 \%$ of diarrhoeic and non-diarhoeic cat isolates, respectively. The $c d t \mathrm{~A}$ and $c d t \mathrm{~B}$ genes were found in $29.2 \%$ and $69.2 \%$ of the diarrhoeic and non-diarhoeic cat isolates, respectively. The flaA gene was found in $26.1 \%$ and $56.9 \%$ of the diarrhoeic and nondiarhoeic cat isolates, respectively. The vir 111 gene was found in $13.8 \%$ and $20 \%$ of the diarrhoeic and non-diarhoeic cat isolates, respectively. 
In two of the diarrhoeic and four of the non-diarhoeic cat isolates, all virulence genes were positive. In addition, the combination and distribution of virulence genes in diarrhoeic and non-diarhoeic cat isolates are presented in Table 4.

All C. jejuni isolates were susceptible to amoxicillin clavulanic acid. The highest resistances of the isolates were found as follows: $64(98.4 \%)$, 63 (96.9\%), 62 (95.3\%) for ciprofloxacin (CIP), trimethoprim sulfamethoxazole (SXT), nalidixic acid (NA) antibiotics, respectively (Table 5). In 64 ciprofloxacin resistant isolates, $20(30.7 \%)$ were diarrhoeic cat isolates and 44 (67.6\%) were non-diarhoeic cat isolates. In 63 trimethoprim sulfamethoxazole resistant isolates, $20(30.7 \%)$ were diarrhoeic cat isolates and $43(66.1 \%)$ of them were non-diarhoeic cat isolates. In 62 nalidixic acid resistant isolates, $20(30.7 \%)$ were diarrhoeic cat isolates and $42(64.6 \%)$ of them were non-diarhoeic cat isolates (Table 5).

Multiple resistance of isolates was detected in the present study. Sixty-one (93.8\%) out of 65 isolates were resistant to three or more antibiotics, where the highest resistance levels to antimicrobials three and seven were observed in $23.1 \%$ and $15.3 \%$ of the isolates, respectively. Thirteen point eight per cent were resistant to antimicrobials five and eight, $10.7 \%$ to antimicrobials four and six and $3.1 \%$ to antimicrobials nine and ten. In total, 15 isolates were resistant to three antimicrobials. Four of them were diarrhoeic and 11 of them were nondiarhoeic cat isolates. MDR levels are presented in Table 6 in terms of diarrhoeic and non-diarhoeic cat isolates. The lowest MDR levels were against 9 and 10 antibiotics. This was equally distributed to both diarrhea and non-diarrhea animals. In addition, the highest MDR levels were found to three antibiotics in 15 isolates $(23.1 \%)$, including 4 and 11 , from diarrhea and non-diarrhea cats, respectively.

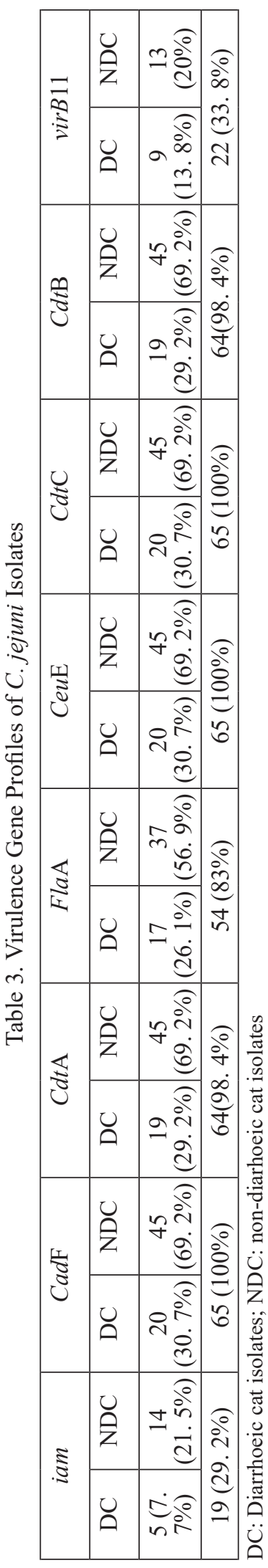

Vet. arhiv 90 (2), 129-141, 2020 
H. Hizlısoy et al.: Putative virulence genes and antibiotic resistance profiles of Campylobacter jejuni isolated from cats

Table 4. The combination and distribution of Virulence Genes in Diarrhoeic and Non-diarhoeic Cat Isolates

\begin{tabular}{|c|c|c|c|}
\hline $\begin{array}{c}\text { No of virulence genes } \\
\text { combinations }\end{array}$ & Genes & DC & NDC \\
\hline 8 & ABCDEFGH & 2 & 4 \\
\hline 7 & BCDEFGH & 5 & 7 \\
\hline 7 & ABCDEFG & 2 & 1 \\
\hline 7 & ABCEFGH & - & 18 \\
\hline 6 & BCDEFG & 7 & 1 \\
\hline 6 & BCEFGH & 1 & 1 \\
\hline 6 & ABCEFG & 1 & 5 \\
\hline 5 & BCEFG & 1 & - \\
\hline 5 & BDEFH & 1 & . \\
\hline
\end{tabular}

A: $i a m$; B: CadF; C: CdtA; D: FlaA; E: CeuE; F: CdtC; G: CdtB; H: VirB11; DC: Number of diarrhoeic cat isolates; NDC: Number of non-diarhoeic cat isolates

Table 5. Antibiotic Resistance Profiles of $C$. jejuni Isolates

\begin{tabular}{|c|c|c|c|c|c|c|c|c|c|}
\hline \multirow[b]{2}{*}{ Antibiotics } & \multicolumn{3}{|c|}{$\mathrm{S}(\%)$} & \multicolumn{3}{|c|}{$\mathrm{I}(\%)$} & \multicolumn{3}{|c|}{$\mathrm{R}(\%)$} \\
\hline & $\mathrm{N}$ & $\mathrm{DC}$ & NDC & $\mathrm{N}$ & $\mathrm{DC}$ & NDC & $\mathrm{N}$ & $\mathrm{DC}$ & NDC \\
\hline Nalidixic acid (NA) & $1(1.5)$ & - & $1(1.5)$ & $2(3.1)$ & - & $2(3.1)$ & $62(95.4)$ & $20(30.7)$ & $42(64.6)$ \\
\hline Erythromycin ( E ) & $64(98.4)$ & $64(98.4)$ & - & - & - & - & $1(1.5)$ & $1(1.5)$ & \\
\hline Doxycycline (DO) & $43(66.1)$ & $15(23.1)$ & $28(43.1)$ & $12(18.5)$ & $2(3.1)$ & $10(15.3)$ & $10(15.3)$ & $5(7.7)$ & $5(7.7)$ \\
\hline $\begin{array}{l}\text { Amoxicillin } \\
\text { clavulanic acid } \\
\text { (AMC) }\end{array}$ & $65(100)$ & $20(30.7)$ & $45(69.2)$ & - & - & - & - & - & - \\
\hline $\begin{array}{l}\text { Trimethoprim } \\
\text { sulfamethoxazole } \\
\text { (SXT) }\end{array}$ & $2(3.1)$ & - & $2(3.1)$ & - & - & - & $63(96.9)$ & $20(30.7)$ & $43(66.1)$ \\
\hline Ciprofloxacin (CIP) & $1(1.5)$ & - & $1(1.5)$ & - & - & - & $64(98.4)$ & $20(30.7)$ & $44(67.6)$ \\
\hline Ampicillin (AMP) & $28(43.1)$ & $9(13.8)$ & $19(29.2)$ & - & - & - & 37 (56.9) & $12(18.5)$ & $25(38.5)$ \\
\hline Enrofloxacin (ENR) & $5(7.7)$ & - & $5(7.7)$ & $29(44.7)$ & $13(20)$ & $16(24.6)$ & $31(47.7)$ & $7(10.7)$ & $24(36.9)$ \\
\hline Clindamycin (DA) & $63(96.9)$ & $20(30.7)$ & $43(66.1)$ & $2(3.1)$ & - & $2(3.1)$ & - & - & - \\
\hline Tetracycline (TE) & $18(27.7)$ & $5(7.7)$ & $13(20)$ & $5(7.7)$ & $2(3.1)$ & $3(4.6)$ & $42(64.6)$ & $13(20)$ & $29(44.7)$ \\
\hline $\begin{array}{l}\text { Piperacillin } \\
\text { tazobactam (TZP) }\end{array}$ & $36(55.4)$ & $10(15.3)$ & $26(40)$ & $16(24.6)$ & $7(10.7)$ & $9(13.8)$ & $13(20)$ & $4(6.2)$ & $9(13.8)$ \\
\hline Cefotaxime (CTX) & $43(66.1)$ & $14(21.5)$ & $29(44.7)$ & $11(16.9)$ & $4(6.2)$ & $7(10.7)$ & $11(16.9)$ & $3(4.6)$ & $8(12.3)$ \\
\hline Streptomycin (S) & $46(70.8)$ & $14(21.5)$ & $32(49.2)$ & $1(1.5)$ & & $1(1.5)$ & $18(27.7)$ & $7(10.7)$ & $11(16.9)$ \\
\hline Amikacin (AK) & $64(98.4)$ & $20(30.7)$ & $44(67.6)$ & - & & $1(1.5)$ & - & - & \\
\hline Gentamicin $(\mathrm{CN})$ & $64(98.4)$ & $20(30.7)$ & $44(67.6)$ & - & - & & $1(1.5)$ & & $1(1.5)$ \\
\hline Azythromycine & $64(98.4)$ & $20(30.7)$ & $44(67.6)$ & - & - & & $1(1.5)$ & & $1(1.5)$ \\
\hline
\end{tabular}

S - Susceptible; I -Intermedier; R- Resistant; N: Number of isolates; DC - Diarrhoeic cat isolates; NDC: - Non-diarhoeic cat isolates. 
H. Hizlısoy et al.: Putative virulence genes and antibiotic resistance profiles of Campylobacter jejuni isolated from cats

Table 6. Multidrug Resistance Profiles of C. jejuni Isolates

\begin{tabular}{|c|c|c|c|c|c|}
\hline Antibiotic numbers & Antibiotic Combinations & $\mathrm{N}$ & DC & NDC & $\%$ \\
\hline \multirow{2}{*}{3} & NA, SXT, CIP & 13 & 4 & 9 & \multirow{2}{*}{23.1} \\
\hline & SXT, CIP, AMP & 2 & - & 2 & \\
\hline \multirow{4}{*}{4} & NA, SXT, CIP, AMP & 2 & 2 & & \multirow{4}{*}{10.7} \\
\hline & NA, SXT, CIP, TE & 2 & & 2 & \\
\hline & NA, SXT, CIP, CTX & 1 & - & 1 & \\
\hline & NA, SXT, CIP, S & 2 & 2 & - & \\
\hline \multirow{3}{*}{5} & NA, SXT, CIP, TE, CTX & 2 & 2 & - & \multirow{3}{*}{13.8} \\
\hline & NA, SXT, CIP, ENR, TE & 3 & 1 & 2 & \\
\hline & NA, SXT, CIP, AMP, TE & 4 & 2 & 2 & \\
\hline \multirow{5}{*}{6} & NA, SXT, CIP, AMP, ENR, CTX & 1 & & 1 & \multirow{5}{*}{10.7} \\
\hline & NA, SXT, CIP, AMP, ENR, TE & 2 & - & 2 & \\
\hline & NA, DO, SXT, CIP, ENR, TE & 2 & - & 2 & \\
\hline & NA, SXT, CIP, AMP, TE, S & 1 & 1 & - & \\
\hline & NA, SXT, CIP, ENR, TE, TZP & 1 & - & 1 & \\
\hline \multirow{4}{*}{7} & NA, SXT, CIP, AMP, ENR, TE, S & 5 & - & 5 & \multirow{4}{*}{15.3} \\
\hline & NA, SXT, CIP, AMP, ENR, TE, TZP & 3 & - & 3 & \\
\hline & NA, E, SXT, CIP, AMP, TE, AZM & 1 & 1 & - & \\
\hline & NA, DO, SXT, CIP, AMP, ENR, TE & 1 & - & 1 & \\
\hline \multirow{6}{*}{8} & NA, DO, SXT, CIP, AMP, ENR, TE, TZP & 1 & 1 & - & \multirow{6}{*}{13.8} \\
\hline & NA, SXT, CIP, AMP, ENR, TE, CTX, S & 2 & - & 2 & \\
\hline & NA, SXT, CIP, AMP, ENR, TE, TZP, S & 1 & 1 & - & \\
\hline & NA, DO, SXT, CIP, AMP, ENR, TE, CN & 1 & 1 & - & \\
\hline & NA, SXT, CIP, AMP, ENR, TE, TZP, CTX & 2 & - & 2 & \\
\hline & NA, DO, SXT, CIP, AMP, ENR, TE, S & 2 & 1 & 1 & \\
\hline \multirow[b]{2}{*}{9} & NA, DO, SXT, CIP, AMP, ENR, TE, TZP, S & 1 & 1 & - & \multirow{2}{*}{ 3. 1} \\
\hline & NA, SXT, CIP, AMP, ENR, TE, TZP, CTX, S & 1 & - & 1 & \\
\hline 10 & NA, DO, SXT, CIP, AMP, ENR, TE, TZP, CTX, S & 2 & 1 & 1 & 3.1 \\
\hline
\end{tabular}

$\mathrm{N}$ - Number of resistance patterns of isolates; DC - number of diarrhoeic cat isolates; NDC - number of non-diarhoeic cat isolates

\section{Discussion}

In the present study, the prevalance of Campylobacter spp. was $20.5 \%$ in the cats examined. The frequency of isolation of Campylobacter spp. in cats ranges from $8 \%$ to $47.8 \%$ globally (SANDBERG et al., 2002; ENGVALL et al., 2003; ACKE et al., 2009a; SALIHU et al., 2010).

Similar to our study, ABAY etal.(2014), SALIHU et al. (2010) and SANDBERG et al. (2002), found prevalences of Campylobacter spp. of $26.7 \%, 18.3 \%$ and $18 \%$ in cats, respectively. However, LAZOU et al. (2017), SZCZEPANSKA et al. (2017) and ANDRZEJEWSKA et al. (2013) found relatively low levels of campylobacters at 15\%,12.1\%,10.5\% and $9.8 \%$ from cats, respectively. The differences in the isolation and identification methods (filtration, using different media, etc.), sample, regional and geographical varieties could be the causes of the low level results. In a study by BAKER et al. 
(1999) in Southern Australia, the filtration method was used for isolation and samples were of different origins. LAZOU et al. (2017), conducted a study in Greece and used mCCD agar and Karmali agar for isolation. In ANDRZEJEWSKA et al. (2013) samples were collected from Poland and were initially inoculated to Preston broth. Later, CCD agar was used for isolation of campylobacters.

Relatively higher results than ours were reported by ACKE et al. (2006; 2009b), who reported Campylobacter species in $75 \%$ and $42.9 \%$ from cat fecal swab samples. In addition, ACKE et al. (2009a) isolated Campylobacter spp. from both healthy and diarrhoeic animals at a rate of $45.2 \%$ in dogs and cats in Ireland.

In terms of the concurrent presence of $C$. jejuni, in the study, different $C$. jejuni isolates were simultaneously found in $19(46 \%)$ cats, similar to SHEN et al. (2001) who reported that $16(34 \%)$ of 47 Campylobacter spp. samples were positive for more than one species of Campylobacter spp. in cat samples. Also, BANG et al. (2001) detected that three chickens with two different $C$. jejuni isolates, and one chicken carrying a $C$. jejuni and a $C$. coli isolate concurrently in Denmark. Also, multiple Campylobacter species were found in $6(26 \%)$ of 23 positive stool samples in dogs (KOENE et al., 2004). In another study conducted by RICHARDSON et al. (2001), in $7.5 \%$ of patients, the presence of concomitant infection with two different types of $C$. jejuni was determined by molecular typing methods, in humans. According to our literature review, this study may be the first report of the simultaneous presence of different $C$. jejuni strains in cats in Turkey. Our data clearly demonstrated that the synchronous existence of different $C$. jejuni strains is quite frequent in cats. It might be of utmost importance for epidemiological studies that different strains are found within a single species, including the commensal presence, for finding the sources of infections, and studies on the pathogenicity of Campylobacter spp. in cats. Moreover, cases of infection with subtypes of one species or more than one species are thought to be important in terms of both the antibacterial susceptibility and the epidemiology of human diseases (KAYMAN et al., 2015).
In our study, there was a statistically significant difference in isolation rate between non-diarhoeic or diarrhoeic cats $(\mathrm{P}<0.05)$, but no statistically significant difference between sex $(\mathrm{P}>0.05)$ and age status in the cats used as subjects $(\mathrm{P}>0.05)$. However, previous studies have reported difference in relation to age and gender in diarrhoeic and healthy animals (BAKER et al., 1999; SANDBERG et al., 2002; ENGVALL et al., 2003).

Since Campylobacter spp. (including $C$. jejuni, C. coli, $C$. lari and C. upsaliensis) is naturally found in the intestinal biota of dogs and cats, cats and dogs exhibit a significant hazard for human campylobacteriosis (OLSON and SANDSTEDT, 1987; NEWTON et al., 1988). Campylobacter spp. might be a primary or secondary pathogen which is related to other predisposing factors, including viral infections or opportunistic agents in pets with other disorders (ACKE et al., 2009a).

In the present study, the $c a d \mathrm{~F}, c d t \mathrm{C}$ and $c e u \mathrm{E}$ genes were found in all $C$. jejuni isolates recovered from the cats. Morever, in this study, all isolates contained at least five virulence genes. Similar results were described by previous studies of animals, and they reported that a high ratio of $f l a \mathrm{~A}$, $c a d \mathrm{~F}$ and $c d t \mathrm{~B}$ genes was found in the analyzed isolates from domestic animals (ANDRZEJEWSKA et al., 2011; KRUTKIEWICZ and KLIMUSZKO, 2010; ANDRZEJEWSKA et al., 2013). Also, RODRIGUES et al. (2015), among the strains of $C$. jejuni isolates detected in dogs, found that two samples (flaA, cad $\mathrm{F}$ and $c i a \mathrm{~B}$, or fla $\mathrm{A}, p l d \mathrm{~A}$ and $c a d \mathrm{~F})$ and two isolates contained the $f a \mathrm{~A}$ gene or $c a d \mathrm{~F}$ and $c i a \mathrm{~B}$ genes, while two isolates contained only one virulence gene ( $c a d \mathrm{~F}$ or $f l a \mathrm{~A})$. BISWAS et al. (2011), in C. jejuni isolates from cattle and humans, $67 \%$ of the isolates contained all of the genes except virB11. The $c a d \mathrm{~F}$ gene was found in $100 \%$ of the isolates tested.

The present study on the antimicrobial susceptibility of strains isolated from cats confirmed a high level of amoxicillin clavulanic acid. The highest level of resistance was to ciprofloxacin (CIP), trimethoprim sulfamethoxazole (SXT), nalidixic acid (NA), and streptomycin (S). Similar results were described in a study conducted by ANDRZEJEWSKA et al. (2013), SANDBERG 
et al. (2002) and SZCZEPANSKA et al. (2017). Due to the use of atimicrobial agents in veterinary practice, resistant Campylobacter isolates from pets and humans have been revealed (GUPTA et al., 2004; ENGBERG et al., 2004). Also, a study conducted in India on the prevalence of antibiotic resistance in dogs showed that isolates had a high rate of resistance $(97.3 \%)$ to cefotaxim, chloramphenicol, floxacin, ciprofloxacin, cefaclor, nitrofurazone, norfloxacin, gentamicin, amikacin and enrofloxacin (KULKARNI et al., 2002). The multiple resistance of isolates was detected in 61 $(93.8 \%)$ out of 65 isolates that were resistant to three or more antibiotics, whereas resistance to three and seven antimicrobials was observed in $23.1 \%$ and $15.3 \%$ of the isolates, respectively (Table 3 ). Our results were relatively compatible with those of SZCZEPANSKA et al. (2017) and GONI et al. (2018), who detected multidrug resistance rates of $40 \%$ and $50 \%$ in Campylobacter spp. isolates, respectively. In addition MDR was also reported by KUMAR et al. (2012).

\section{Conclusion}

In conclusion, the data obtained in this study reveal that the high prevalence of virulenceassociated genes among $C$. jejuni isolates obtained from cats suggests their crucial role in the pathogenesis of campylobacteriosis infection among cats, and their close contact with humans.

Moreover, the presence of multidrug resistant C. jejuni isolates indicates a potential transmission risk from cats to humans.

\section{Funding sources}

This work was not funded by any project.

\section{Conflicts of interest}

The authors declare no conflict of interest.

\section{Acknowledgment}

We are grateful to Assoc. Prof. Dr. Nurhan Ertas ONMAZ for her technical assistance. We also thank to Assoc. Prof. Dr. Aytac AKCAY at Erciyes University, Faculty of Veterinary Medicine, Department of Biometri.

\section{References}

ABAY, S., T. KAYMAN, H. HIZLISOY, F. AYDIN (2012): In vitro antibacterial susceptibility of Arcobacter butzleri isolated from different sources. J. Vet. Med. Sci. 74, 613616.

DOI: 10.1292/jvms.11-0487

ABAY, S., F. AYDIN, H. HIZLISOY, V. GUNES (2014): Recovery of thermophilic Campylobacter spp. in healthy and diarrhoeic pets by culture methods and identification of the isolates by multiplex polymerase chain reaction (mPCR), Kafkas Univ. Vet. Fak. Derg. 20, 735-741.

DOI: $10.9775 / \mathrm{kvfd} .2014 .11010$

ACKE, E., P. WHYTE, B. R. JONES, K. MCGILL, J. D. COLLINS, S. FANNING (2006): Prevalence of thermophilic Campylobacter species in cats and dogs in two animal shelters in Ireland. Vet. Rec. 158, 51-54.

DOI: $10.1136 /$ vr.158.2.51

ACKE, E., K. MCGILL, O. GOLDEN, B. R. JONES, S. FANNING, P. WHYTE (2009a): Prevalence of thermophilic Campylobacter species in household cats and dogs in Ireland. Vet. Rec. 164, 44-47.

DOI: $10.1136 /$ vr.164.2.44

ACKE, E., K. MCGILL, O. GOLDEN, B. R. JONES, S. FANNING, P. WHYTE (2009b): A comparison of different culture methods for the recovery of Campylobacter species from pets. Zoonoses Public Health 56, 490-495.

DOI: $10.1111 / \mathrm{j} .1863-2378.2008 .01205 . x$

ACKE, E. (2018): Campylobacteriosis in dogs and cats: a review, NZ Vet. J. 66, 221-228.

DOI: $10.1080 / 00480169.2018 .1475268$

ANDRZEJEWSKA, M, J. J. KLAWE, B. SZCZEPAŃSKA, D. ŚPICA (2011): Occurence of virulence genes among Campylobacter jejuni and Campylobacter coli isolates from domestic animals and children. Pol. J. Vet. Sci. 14, 207-211.

DOI: $10.2478 / \mathrm{v} 10181-011-0031-\mathrm{x}$

ANDRZEJEWSKA, M., B. SZCZEPAŃSKA, J. J. KLAWE, D. ŚPICA, M. CHUDZIŃSKA (2013): Prevalence of Campylobacter jejuni and Campylobacter coli species in cats and dogs from Bydgoszcz (Poland) region. Pol. J. Vet. Sci. 16, 115-120.

DOI: $10.2478 /$ pjvs-2013-0016

BAKER, J., M. D. BARTON, J. LANSER (1999): Campylobacter species in cats and dogs in South Australia. Aust. Vet. J. 77, 662-666.

DOI: 10.1111/j.1751-0813.1999.tb13159.x

BANG, D. D., F. SCHEUTZ, P. AHRENS, K. PEDERSEN, J. BLOM, M. MADSEN (2001): Prevalence of cytolethal, distending toxin (cdt) genes and CDT production in Campylobacter spp. isolated from Danish broilers. J. Med. Microbiol. 50, 1087-1094.

DOI: $10.1099 / 0022-1317-50-12-1087$ 
BISWAS, D., S. J. HANNON, H. G. G. TOWNSEND, A. POTTER, B. J. ALLAN (2011): Genes coding for virulence determinants of Campylobacter jejuni in human clinical and cattle isolates from Alberta, Canada, and their potential role in colonization of poultry. Int Microbiol. 4, 25-32.

DOI: $10.2436 / 20.1501 .01 .132$

BOJANIĆ, K., A. C. MIDWINTER, J. C. MARSHALL, L. E. ROGERS, P. J. BIGGS, E. ACKE (2017): Isolation of Campylobacter spp. from client-owned dogs and cats, and retail raw meat pet food in the Manawatu. New Zealand. Zoonoses Public Health 64, 438-449.

DOI: $10.1111 /$ zph.12323

CASABONNE, C., A. GONZALEZ, V. AQUILI, T. SUBILS, C. BALAGUE (2016): Prevalence of seven virulence genes of Campylobacter jejuni isolated from Patients with diarrhea in Rosario. Argentina. Int. J. Infect. 3(4), e37727

DOI: $10.17795 / \mathrm{iji}-37727$

CHANSIRIPORNCHAI, N., J. SASIPREEYAJAN (2009): PCR detection of four virulence-associated genes of Campylobacter jejuni isolates from Thai broilers and their abilities of adhesion to and invasion of INT-407 cells. J. Vet. Med. Sci. 71, 839-844.

DOI: 10.1292/jvms.71.839

CLINICALAND LABORATORY STANDARDS INSTITUTE (2014): Clinical and Laboratory Standards Institute (CLSI) Performance standards for antimicrobial susceptibility testing; Twenty-Fourth Informational Supplement. CLSI document M100-S24. Wayne, PA: Clinical and Laboratory Standards Institute.

DATTA, S., H. NIWA, K. ITOH (2003): Prevalence of 11 pathogenic genes of Campylobacter jejuni by PCR in strains isolated from humans, poultry meat and broiler and bovine faeces. J. Med. Microbiol. 52, 345-348.

DOI: $10.1099 / \mathrm{jmm} .0 .05056-0$

ENGBERG, J., J. NEIMANN, E. M. NIELSEN, F. M. AARESTRUP, F. M. FUSSING, 2004. Quinolone-resistant Campylobacter infections in Denmark: risk factors and clinical consequences. Emerg. Infect. Dis. 10, 1056-1063. DOI: 10.3201/eid1006.030669

ENGVALL, E. O., B. BRANDSTROM, L. ANDERSSON, V. BAVERUD, G. TROWALD-WIGH, L. ENGLUND (2003): Isolation and identification of thermophilic Campylobacter species in faecal samples from Swedish dogs. Scand. J. Infect. Dis. 35, 713-718.

DOI: $10.1080 / 00365540310014558$

FOX, J. G. (2012): Enteric Bacterial Infections, In: Infectious Disesases of Dog and Cat. (Greene, C. E., Ed.), $4^{\text {th }}$ ed., Saunders Elsevier, St. Louis Missouri USA, p. 371.

GONI, M. D., A. Y. OSMAN, S. A. AZIZ, Z. ZUNITA, G. K. DHALIWAL, M. I. JALO, A. A. BITRUS, M. JAJERE, M. A. ABBAS (2018): Antimicrobial resistance of Campylobacter spp. and Arcobacter butzleri from pets in Malaysia. J. Am. Vet. Med. Assoc. 13, 152-161.

DOI: 10.3844 ajavsp.2018.152.161
GUPTA, A., J. M. NELSON, T. J. BARRETT, R. V. TAUXE, S. P. ROSSITER, C. R. FRIEDMAN, K. W. JOYCE, K. E. SMITH, T. F JONES, M. A. HAWKINS, B. SHIFERAW, J. L. BEEBE, D. J. VUGIA, T. RABATSKY-EHR, J. A. BENSON, T. P. ROOT, F. J. ANGULO, NARMS WORKING GROUP (2004). Antimicrobial resistance among Campylobacter strains, United States, 1997-2001. Emerg. Infect. Dis. 10, 1102-1109.

DOI: $10.3201 /$ eid1006.030635

HEREDIA, N., S. GARCIA(2018): Animals as sources of foodborne pathogens: A review. Animal Nutrition 4, 250-255. DOI: 10.1016/j.aninu.2018.04.006

HOUF, K., L. DE ZUTTER, J. VAN HOOF, P. VANDAMME (2002): Assessment of the genetic diversity among arcobacters isolated from poultry products by using two PCR-based typing methods. Appl. Environ. Microbiol. 68, 2172-2178.

DOI: 10.1128/AEM.68.5.2172-2178.2002

KAAKOUSH, N. O., N, CASTANO-RODRI'GUEZ, H. M. MITCHELL, S. M. MAN (2015): Global Epidemiology of Campylobacter Infection. Clin. Microbiol. Rev. 28, 687720.

DOI: 10.1128/CMR.00006-15

KAYMAN, T., F. AYDIN, S. ABAY, K. S. DIKER (2015): Coinfection with Campylobacter jejuni subtypes in patients with acute gastroenteritis. Türk Mikrobiyol. Cem. Derg. 45, 117-121 (in Turkish).

DOI: $10.5222 /$ TMCD.2015.117

KHOSHBAKHT, R., M. TABATABAEI, S. HOSSEINZADEH, SS. SHEKARFOROUSH, H. S. ASKI (2013): Distribution of nine virulence-associated genes in Campylobacter jejuni and $C$. coli isolated from broiler feces in Shiraz, Southern Iran. Foodborne Pathog. Dis. 10, 764-770.

DOI: $10.1089 /$ fpd.2013.1489

KOENE, M. G., D. J. HOUWERS, J. R. DIJKSTRA, B. DUIM, J. A. WAGENAAR (2004): Simultaneous presence of multiple Campylobacter species in dogs. J. Clin. Microbiol. 42, 819-821.

DOI: $10.1128 / J C M .42 .2 .819-821.2004$

KOOLMAN, L., P. WHYTE, C. BURGESSA, D. BOLTON (2016): Virulence gene expression, adhesion and invasion of Campylobacter jejuni exposed to oxidative stress, Int. J. Food Microbiol. 220, 33-38.

DOI: 10.1016/j.ijfoodmicro

KRUTKIEWICZ, A., D. KLIMUSZKO (2010): Genotyping and PCR detection of potential virulence genes in Campylobacter jejuni and Campylobacter coli isolates from different sources in Poland. Folia Microbiol. (Praha). $55,167-175$.

DOI: $10.1007 / \mathrm{s} 12223-010-0025-6$

KULKARNI, S. P., S. LEVER, J. M. LOGAN, A. LAWSON, J. STANLEY, M. S. SHAFI (2002). Detection of Campylobacter species: a comparison of culture and 
polymerase chain reaction based methods. J. Clin. Pathol. $55,749-753$.

DOI: $10.1136 /$ jep.55.10.749

KUMAR, R., A. K., VERMA, A,. KUMAR, M., SRIVASTAVA, H. P. LAL (2012): Prevalence of Campylobacter sp. in dogs attending veterinary practices at Mathura, India and risk indicators associated with shedding. Asian J. Anim. Vet. Adv. 7, 754-760.

DOI: 10.3923/ajava.2012.754.760

LARSON, C. L., J. E. CHRISTENSEN, S. A. PACHECO, S. A. MINNICH, M. E. KONKEL (2008): Campylobacter jejuni Secretes Proteins via the Flagellar Type III Secretion System That Contribute to Host Cell Invasion and Gastroenteritis. In: Campylobacter. (Nachamkin, I., C. M. Szymanski, M. J. Blaser, Eds), ASM Press, Washington DC, pp 314-332.

LAZOU, T., F. FRAGKOU, A. GELASAKIS, C. DOVAS, N. SOULTOS, K. ADAMAMA-MORAITOU, E. IOSSIFIDOU (2017): Prevalence, antimicrobial resistance and risk factors for Campylobacter colonising dogs and cats in Greece. BJVM. 20, 244-254.

DOI: $10.15547 /$ bjvm.1003

LINDMARK, H., S. BOQVIST, M. LJUNGSTRÖM, P. ÅGREN, B. BJÖRKHOLM, L. ENGSTRAND (2009): Risk factors for campylobacteriosis: an epidemiological surveillance study of patients and retail poultry. J. Clin. Microbiol. 47, 2616-2619.

DOI: $10.1128 /$ JCM.00826-09

MAGIORAKOS, A. P., A. SRINIVASAN, R. B. CAREY, Y. CARMELI, M. E. FALAGAS, C. G. GISKE (2012): Multidrug-resistant, extensively drug-resistant and pandrug-resistant bacteria: an international expert proposal for interim standard definitions for acquired resistance. Clin. Microbiol. Infect. 18, 268-281.

DOI: $10.1111 /$ j.1469-0691.2011.03570.x

MARTINEZ, I., E. MATEO, E. CHURRUCA, C. GIRBAU, R. ALONSO, A. FERNÁNDEZ-ASTORGA (2006): Detection of $c d t \mathrm{~A}, c d t \mathrm{~B}$, and $c d t \mathrm{C}$ genes in Campylobacter jejuni by multiplex PCR. Int. J. Med. Microbiol. 296, 4548.

DOI: 10.1016/j.ijmm.2005.08.003

NEWTON, C. M, D. G. NEWELL, M. WOOD, M. BASKERVILLE (1988): Campylobacter infection in a closed dog breeding colony. Vet. Rec. 123, 152-154.

DOI: $10.1136 /$ vr.123.6.152

NIKAIDO, H (2009): Multidrug resistance in bacteria. Annu Rev. Biochem. 78, 119-146.

DOI: 10.1146/annurev.biochem.78.082907.145923

OLSON, P., K. SANDSTEDT (1987): Campylobacter in the dog: a clinical and experimental study. Vet. Rec. 121, 99101.

DOI: $10.1136 /$ vr.121.5.99

QUETZ, J. da S., I. F. N. LIMA, A. HAVT, M. M. PRATA, P. A. CAVAlCANTE, P. H. MEDEIROS, D. A. CID, M.
L. MORAES, L. C. REY, A. M. SOARES, R. M. MOTA, B. H. WEIGL, R. L GUERRANT, A. A. LIMA (2012): Campylobacter jejuni infection and virulence associated genes in children with moderate to severe diarrhoea admitted to emergency rooms in Northeastern Brazil. J. Med. Microbiol. 61, 507-513.

DOI: 10.1099/jmm.0.040600-0

RICHARDSON, J. F., J. A. FROST, J. M. KRAMER (2001): Coinfection with Campylobacter species: an epidemiological problem? J. Appl. Microbiol. 91, 206-211. DOI: 10.1046/j.1365-2672.2001.01377.x

RIPABELLI, G., M. TAMBURRO, F. MINELLI, A. LEONE, M. L. SAMMARCO (2010): Prevalence of virulenceassociated genes and cytolethal distending toxin production in Campylobacter spp. isolated in Italy. Comp. Immunol. Microbiol. Infect. Dis. 33, 355-364.

DOI: $10.1016 /$ j.cimid.2008

RODRIGUES, C. G, R. T. MELO, B. B. FONSECA, P. A. MARTINS, F. A. FERREIRA, M. B. J. ARAUJO, D. A. ROSSI (2015): Occurrence and characterization of Campylobacter spp. isolates in dogs, cats and children. EMBRAPA. 35, 365-370.

DOI: $10.1590 / \mathrm{S} 0100-736 \mathrm{X} 2015000400009$

SALIHU, M. D., A. A. MAGAJI, J. U. ABDULKADIR, A. KOLAWALE (2010): Survey of thermophilic Campylobacter species in cats and dogs in north-western Nigeria. Vet. Ital. 46, 425-430.

SANDBERG, M., B. BERGSJO, M. HOFSHAGEN, E. SKJERVE, H. KRUSE (2002): Risk factors for Campylobacter infection in Norwegian cats and dogs. Prev. Vet. Med. 55, 241-253.

DOI: 10.1016/S0167-5877(02)00095-8

SHEN, Z., Y. FENG, F. E. DEWHIRST, J. G. FOX (2001): Coinfection of enteric Helicobacter spp. and Campylobacter spp. in cats. J. Clin. Microbiol. 39, 2166-2177.

DOI: 10.1128/JCM.39.6.2166-2172.2001

SPSS (Statistical Package for Social Sciences) for Windows Version 23. 0, Armonk, NY, IBM Corp. USA.

SZCZEPANSKA, B., M. ANDRZEJEWSKA, D. SPICA, J. J. KLAWE (2017): Prevalence and antimicrobial resistance of Campylobacter jejuni and Campylobacter coli isolated from children and environmental sources in urban and suburban areas. BMC Microbiol. 17, 80.

DOI: 10.1186/s12866-017-0991-9

VANDAMME, P., J. DE LEY (1991): Proposal for a new family, Campylobacteraceae. Int. J. Syst Bacteriol. 41, 451-455.

DOI: $10.1099 / 00207713-41-3-451$

WANG, G., G. C. CLIFFORD, M. T. TRACY (2002): Colony multiplex PCR assay for identification and differentiation of Campylobacter jejuni, C. coli, C. lari, C. upsaliensis, and C. fetus subsp. fetus. J. Clinical Microbiol. 40, 4744-4747. DOI: $10.1128 /$ JCM.40.12.4744-4747.2002 
Received: 17 May 2019

Accepted: 21 October 2019

HIZLISOY, H., İ. KARACA BEKDIK, Ö. ASLAN, K. S. GÜMÜŞSOY, S. HIZLISOY: Geni potencijalne virulencije i profili antibiotske rezistencije bakterije Campylobacter jejuni izolirane iz mačaka. Vet. arhiv 90, 129-141, 2020.

\section{SAŽETAK}

Svakodnevni kontakt s mačkama znatan je čimbenik rizika za kampilobakteriozu u ljudi. Glavni je cilj ovoga rada bio istražiti gene virulencije i antibiotsku rezistenciju bakterije $C$. jejuni izolirane iz izmeta mačaka dovedenih na Erciyes University, Faculty of Veterinary Medicine, Training and Research Hospital Clinics. Izmet je uzet od 200 mačaka (116 ženki i 84 mužjaka) različitih pasmina i dobi (1 mjesec do 9 godina), od svibnja 2017. do travnja 2018. Izolati Campylobacter spp. identificirani su na razini roda i vrste primjenom genski specifičnog multipleks PCR-a (mPCR) kojim je ustanovljena prisutnost gena $i a m, c a d \mathrm{~F}, c d t \mathrm{~A}, f l a \mathrm{~A}, c e u \mathrm{E}, c d t \mathrm{C}, c d t \mathrm{~B}$ i $v i r B 11$. Antimikrobna rezistencija i otpornost na širok spektar lijekova (MDR) izolata određeni su disk-difuzijskim testom. Primjenom Enterobacterial Repetitive Intergenic Consensus Polymerase Chain Reaction (ERIC-PCR) otkriveni su genski srodnici izolata. U ovom je istraživanju $41(20,5 \%)$ od 200 uzoraka izmeta bio pozitivan na Campylobacter spp. Među pozitivnim uzorcima njih 14 od $22(63,6 \%)$ potjecalo je od mačaka koje su imale proljev, a 27 od $178(15,1$ $\%$ ) uzoraka bilo je od mačaka koje nisu imale proljev. Fenotipski testovi i PCR pokazali su da je 65 izolata (20 od njih potjecalo je od mačaka koje su imale proljev i 45 od mačaka koje nisu imale proljev) identificirano kao $C$. jejuni. Razlike u broju izolata s obzirom na spol i dob nisu bile statistički znakovite $(\mathrm{P}>0,05)$. Svi izolati $C$. jejuni imali su barem pet gena virulencije i bili pozitivni na gene $c a d \mathrm{~F}, c d t \mathrm{C}$ i $c e u \mathrm{E}$. Gen iam sadržavalo je 19 izolata $C$. jejuni $(29,2$ $\%)$, gen $c a d \mathrm{~F} 65$ izolata (100\%), gen $c d t$ A 64 izolata (98,4\%), gen flaA 54 izolata (83\%), gen ceu E 65 izolata (100 $\%)$, gen $c d t \mathrm{C} 65$ izolata (100\%), gen $c d t \mathrm{~B} 64$ izolata (98,4 \%) i gen $v i r \mathrm{~B} 1122$ izolata (33,8 \%). Geni toksina $c d t \mathrm{~A}$ i $c d t \mathrm{~B}$ pronađeni su u većini analiziranih izolata. Svi su izolati $C$. jejuni bili osjetljivi na amoksicilin-klavulansku kiselinu. Najveća rezistencija bila je: 64 izolata (98, 4 \%) na ciprofloksacin (CIP), 63 izolata (96,9\%) na trimetoprimsulfametoksazol (SXT) i 62 izolata (95,3 \%) na nalidiksičnu kiselinu (NA). U ovom je istraživanju ustanovljena višestruka rezistencija izolata. 61 od 65 izolata $(93,8 \%$ ) bilo je otporno na tri ili više antibiotika, a najveća je otpornost utvrđena na tri antimikrobna lijeka u 23,1 \% izolata i na sedam antimikrobnih lijekova u 15,3\% izolata. Istraživanjem je ustanovljena otpornost izolata $C$. jejuni na većinu antibiotika koji se trenutačno primjenjuju te iznimna svojstva virulencije u mačaka, koja mogu imati određeni rizik za javno zdravstvo.

Ključne riječi: Campylobacter jejuni; virulencija; antibiotska rezistencija; ERIC-PCR 
